$\mathrm{Hal}: 36-42$

\title{
PENINGKATAN KEMAMPUAN PENALARAN INDUKTIF MATEMATIK SISWA MATERI LOGIKA MATEMATIKA DENGAN MENERAPKAN MODEL PEMBELAJARAN CONTEXTUAL TEACHING AND LEARNING KELAS X-2 SMA N 1 TORGAMBA
}

\section{IMPROVEMENT OF MATHEMATICAL INDUCTIVE REASONING ABILITY OF STUDENTS IN MATHEMATICAL PRINCIPAL BY IMPLEMENTING CONTEXTUAL TEACHING AND LEARNING MODELS OF CLASS X-2 OF SMA N 1 TORGAMBA}

\author{
WARNI', NURLINA ARIANI HRP ${ }^{2}$ \\ ${ }^{1}$ Program Studi Pendidikan Matematika, FKIP Universitas Labuhanbatu \\ Jalan Sisingamangaraja No. 126A, KM, 3,5 Aek Tapa Rantauprapat email: warni12@yahoo.com \\ ${ }^{2}$ Program Studi Pendidikan Matematika, FKIP Universitas Labuhanbatu \\ Jalan Sisingamangaraja No. 126A, KM, 3,5 Aek Tapa Rantauprapat email: nurlinaariani@yahoo.com
}

\begin{abstract}
Abstrak
Penelitian ini bertujuan untuk mengetahui pengaruh model Pembelajaran Student Teams Achievement Division (STAD) terhadap kemampuan pemecahan masalah matematika kelas VIII SMP Muhammadiyah 25 Rantauprapat tahun pembelajaran 2017/2018 dan untuk mengetahui pola jawaban siswa dalam pemecahan masalah matematika. Teknik pengumpulan data diperoleh dengan cara tes berupa soal uraian. Instrument penelitian yang digunakan adalah soal pre-test dan post-test sebanyak 3 soal uraian. Teknik analisis data yang digunakan adalah uji normalitas, uji homogenitas, uji t dengan teknik paired samples $t$-test. Berdasarkan hasil penelitian, diperoleh nilai rata-rata kelas sebelum perlakuan sebesar 11,79 dan setelah perlakuan menjadi 18,73, juga terlihat pada pola jawaban siswa sebelum diberikan perlakuan memiliki nilai kategori sedang 24 orang dan kategori rendah 9 orang namun setelah diberi perlakuan memiliki nilai kategori tinggi 12 orang dan sedang 21 orang. Pada hasil uji t diperoleh nilai thitung sebesar 11,601, dan tabel sebesar 2,037, maka 11,601 > 2,037 dengan tingkat signifikan 0,000<0,05 maka $\mathrm{H}_{\mathrm{o}}$ ditolak dan $\mathrm{H}_{\mathrm{a}}$ diterima. Artinya, ada pengaruh model Pembelajaran Student Teams Achievement Division (STAD) terhadap kemampuan pemecahan masalah matematika. Pola jawaban siswa dalam memecahkan masalah matematika pada penyelesaian soal post-test lebih baik daripada penyelesaian soal pre-test. Dimana siswa mampu memahami merencanakan, melaksanakan rencana dan memeriksa kembali jawaban dengan tuntas dan benar.
\end{abstract}

Kata kunci : Pembelajaran Student Teams Achievement Division (STAD), Kemampuan Pemecahan Masalah Matematika

\begin{abstract}
This study aims to determine the effect of Learning Model Student Teams Achievement Division (STAD) on the ability to solve mathematics problems class VIII SMP Muhammadiyah 25 Rantauprapat year of learning 2017/2018 and to know the pattern of student answers in mathematical problem solving. Technique of collecting data obtained by test in the form of description problem. The research instrument used is a matter of pre-test and post-test of 3 questions description. Data analysis techniques used are normality test, homogeneity test, $t$ test with paired samples t-test technique. Based on the result of research, we get the average value of class before treatment 11,79 and after treatment become 18,73, also seen in the pattern of answers before the students were given the treatment has a moderate category 24 people and low category 9 people but after being treated has a high category category 12 people and 21 people. In t test results obtained tcount of 11.601, and ttable of 2.037, then 11.601>2.037 with a significant level of $0.000<0.05$ then $\mathrm{Ho}$ is rejected and Ha accepted. That is, there is influence of Learning Model Student Teams Achievement Division (STAD) to the ability of problem solving mathematics. The pattern of students' answers in solving mathematical problems in solving post-test problems is better than solving pre-test problems. Where students are able to understand the plan, execute the plan and re-examine the answers thoroughly and correctly.
\end{abstract}

Key Words : Learning of Student Teams Achievement Division (STAD), Mathematical Problem Solving Ability

Peningkatan Kemampuan Penalaran Induktif Matematik Siswa pada Materi Logika Matematika dengan Menerapkan Model Pembelajaran 


\section{Pendahuluan}

Kemampuan penalaran yang tertuang dalam permendiknas No. 22 tahun 2006 tentang standar isi (SI) merupakan salah satu dari kompetensi yang harus dimiliki oleh peserta didik. Penalaran merupakan suatu kegiatan, suatu proses atau suatu aktivitas berpikir untuk menarik kesimpulan atau membuat suatu pernyataan baru yang benar berdasarkan beberapa pernyataan yang kebenarannya telah dibuktikan atau diasumsikan sebelumnya. Penalaran dibedakan menjadi dua yaitu penalaran induktif dan penalaran deduktif. Melalui penalaran matematika siswa dapat mengajukan dugaan kemudian menyusun bukti,melakukan manipulasi terhadap permasalahan (soal) matematika dan menarik kesimpulan dengan benar dan tepat.

Depdiknas menyatakan bahwa "materi matematika dan penalaran matematika merupakan dua hal yang tidak dapat dipisahkan yaitu materi matematika dipahami melalui penalaran dan penalaran dipahami dilatih melalui belajar materi matematika."kemampuan bernalar tidak hanya dibutuhkan para siswa pada saat pembelajaran matematika ataupun mata pelajaran lainnya,namun sangat dibutuhkan ketika siswa dituntut untuk memecahkan masalah dan mengambil kesimpulan dalam permasalahan hidup.mencermati begitu pentingnya kemampuan penalaran pada pembelajaran matematika maka siswa dituntut untuk memiliki kemampuan ini[1].

Berdasarkan informasiyang penulis peroleh dari salah satu guru mata pelajaran matematika di SMA Negeri 1 Torgamba, bahwa rata-rata kemampuan penalaran siswa masih tergolong rendah. Hal ini terlihat dari nilai ulangan harian siswa yang masih sebagian besar dibawah Kriteria Ketuntasan Minimal (KKM) yaitu 65. Dari analisa soal ulangan harian, siswa belum terampil mengajukan conjecture (menduga)dari suatu pernyataan, siswa masih kesulitan menyusun bukti, memberikan alasan dan belum terampil menarik kesimpulan dari suatu pernyataan matematika yang semua itu merupakan indikator penalaran. Lemahnya kemampuan penalaran siswa dipengaruhi oleh beberapa faktor, salah satunya adalah realita pembelajaran matematika cenderung abstrak dengan metode ceramah sehingga konsepkonsep matematika sulit dipahami. Siswa hanya menghapal rumus dan langkah-langkah pengerjaan soal tanpa melibatkan daya nalar yang optimal.

Dampak lebih lanjut adalah banyak siswa mampu menyajikan tingkat hapalan yang baik terhadap suatu materi ajar yang diterimanya,tetapi pada kenyataannnya mereka tidak memahamibagaimanapengetahuan tersebut akan bermanfaat dalam kehidupannya[2].

Pembelajaran Contextual Teaching and Learning merupakan konsep yang membantu guru mengaitkan antara materi yang diajarkan dengan situasi dunia nyata dan mendorong siswa membuat hubungan antara pengetahuan yang dimilikinya dengan penerapannya dalam kehidupan mereka[3]. Ciri khas dari Contextual Teaching and Learning adalah adanya proses matematisasi harizontal yang merupakan jembatan antara dunia real dengan dunia abstrak melalui alat atau model benda tertentu untuk memperoleh jawaban informal. Proses matematisasi harizontal ini merupakan cara untuk melatih penalaran induktif siswa. Karna penalaran induktif didapat dari pemodelan ataupun melihat pola dari benda-benda yang bersifat khusus menuju suatu kesimpulan yang bersifat umum.

Tabel 1: langkah-langkah model pembelajaran contextual teaching and learning

\begin{tabular}{|c|l|l|}
\hline No & \multicolumn{1}{|c|}{ Bagi Guru } & \multicolumn{1}{|c|}{ Bagi Siswa } \\
\hline 1 & Membantu membentuk konsep & $\begin{array}{l}\text { Berpartisipasi secara aktif dalam } \\
\text { membentuk ide baru }\end{array}$ \\
\hline 2 & Membangkitkan respon siswa & Menggali informasi \\
\hline 3 & Cara berpikir yang sistematis & $\begin{array}{l}\text { Untuk pembentukan kreativitas } \\
\text { siswa }\end{array}$ \\
\hline 4 & $\begin{array}{l}\text { Menyarankan agar hasil pembelajaran } \\
\text { diperoleh dari kerjasama dengan yang } \\
\text { lain }\end{array}$ & Saling tukar pendapat antar siswa \\
\hline 5 & Dengan mengerjakan sesuatu & Mengamati suatu model \\
\hline
\end{tabular}




\begin{tabular}{|c|l|l|}
\hline 6 & Guru menyisakan waktu sejenak & Menghilangkan rasa kejenuhan \\
\hline 7 & Membuat tugas siswa & Menjawab pertanyaan atau tugas \\
\hline
\end{tabular}

Oleh Karena itu, peneliti memilih pembelajaran Contextual Teaching and Learning (CTL) sebagai alternatif dalam menyikapi masalah rendahnya kemampuan penalaran induktif matematika siswa kelas X2 SMA N 1 Torgamba.

\section{Metode Penelitian}

Jenis penelitian ini adalah Penelitian Tindakan Kelas (PTK) atau Classroom Action Research (CAR). PTK adalah suatu penelitian yang dilakukan oleh guru kelas di sekolah tempat ia mengajar dengan penekanan pada penyempurnaan atau peningkatan proses dan praktis pembelajaran[4]. Penelitian ini dilaksanakan di SMA N 1 Torgamba Kabupaten Labuhanbatu Selatan karena di SMA N 1 Torgamba menggunakan model pembelajaran ceramah sehingga pembelajaran kurang efektif oleh karena itu saya menggunakan model pembelajaran CTL untuk peningkatan kemampuan siswa dan diadakan pada bulan Mei. Subjek dalam penelitian ini adalah kelas X-2 berjumlah 40 orang yang terdiri 16 siswa Laki-laki dan 24 siswa Perempuan.

Adapun instrumen penelitian ini adalah tes berbentuk pilihan ganda dan esai serta observasi kegiatan siswa selama kegiatan belajar mengajar. Tes hasil belajar disusun dalam bentuk pilihan ganda/post tes yang berjumlah 20 soal telah divalidkan yaitu terdiri dari 5 (lima) jawaban (option) dan tes hasil belajar juga disusun dalam bentuk esai/free tes yang berjumlah 5 soal telah divalidkan.isi tes mencakup seluruh materi pokok logika mattematika.

Prosedur penelitian dalam penelitian ini dilakukan dengan langkah-langkah sebagai berikut :

SIKLUS I

1. Permasalahan I

Data yang diperoleh dari hasil refleksi tes awal dilakukan Perencanaan tindakan untuk mengatasi masalah tersebut. Serta mengetahui masalah-masalah yang belum dipahami siswa berdasarkan tes awal.

2. Pemecahan I (Rencana Tindakan I)

a) Membuat RPP dengan menerapkan model pembelajaran Contextual Teaching and Learning

b) Menyampaikan materi pelajaran tentang operasi pada Logika Matematika yang melibatkan siswa secara individual

c) Membagi siswa dalam beberapa kelompok yang terdiri dari 4-5 orang siswa yang berbeda tingkat kemampuannya

d) Berdialog dengan siswa tentang tujuan pembelajaran dan mengaitkan materi yang akan dipelajari dengan kehidupan nyata/sehari-hari

e) Menyusun soal-soal pada lembar LKS sebagai bahan penilaian setiap pertemuan

f) Membuat tes nilai belajar

g) Megajukan pertanyaan melalui pemberian LKS sehingga siswa dapat melakukan pengamatan dan mengumpulkan informasi

3. Observasi 1

Observasi dalam hal ini adalah guru SMA N 1 Torgamba guna mengamati kegiatan yang dilakukan oleh guru peneliti dan melihat aktifitas siswa selama kegiatan pembelajaran berlangsung yang berpedoman pada lembar observasi.

4. Evaluasi 1

Melakukan evaluasi terhadap pelaksanaan kegiatan yang dilakukan berdasarkan rencana kegiatan guna untuk mengetahui hasil gambaran kemampuan penalaran induktif siswa.

5. Refleksi 1

Data hasil observasi dan evaluasi dianalisis untuk mengetahui tingkat kemampuan penalaran induktif siswa dalam memecahkan masalah, jika 85\% dari siswa mencapai tingkat Persentasi Kemampuan Penalaran Induktif Matematika (PKPIM) tinggi, maka dilanjutkan pada siklus II.

SIKLUS II

1. Permasalah II

Data yang diperoleh dari siklus I diidentitas dan dilakukan perencanaan tindakan selanjutnya karena mengetahui kesulitan yang masih dialami siswa dalam menyelesaikan soal.

2. Alternatif Pemecahan II (Tindakan II)

a) Membuat RPP dengan menerapkan model pembelajaran Contextual Teaching and Learning 
b) Menyampaikan materi pelajaran tentang operasi pada Logika Matematika yang melibatkan siswa secara individual

c) Membagi siswa dalam beberapa kelompok yang terdiri dari 4-5 orang siswa yang berdeda tingkat kemampuannya

d) Berdialog dengan siswa tentang tujuan pembelajaran dan mengaitkan materi yang akan dipelajari dengan kehidupan nyata/sehari-hari

e) Menyusun soal-soal pada lembar LKS sebagai bahan penilaian setiap pertemuan

f) Membuat tes nilai belajar II

g) Megajukan pertanyaan melalui pemberian LKS sehingga siswa dapat melakukan pengamatan dan mengumpulkan informasi.

3. Observasi II

Observasi dalam hal ini adalah guru SMA N 1 Torgamba guna mengamati kegiatan yang dilakukan oleh guru peneliti dan melihat aktifitas siswa selama kegiatan pembelajaran berlangsung yang berpedoman pada lembar observasi sesuai dengan RPP. Interaksi peneliti dengan siswa serta letak kendala dalam melaksanakan pembelajaran.

4. Evaluasi II

Melakukan evaluasi terhadap pelaksanaan kegiatan yang dilakukan berdasarkan rencana kegiatan guna untul mengetahui hasil gambaran kemampuan penalaran induktif siswa.

5. Refleksi II

Data hasil observasi dan evaluasi dianalisis untuk mengetahui tingkat kemampuan penalaran induktif siswa dalam memecahkan masalah, jika $85 \%$ dari siswa mencapai tingkat Persentasi Kemampuan Penalaran Induktif Matematik (PKPIM) maka dilanjutkan pada siklus selanjutnya, tetapi jika sudah tercapai maka tindakan akan berhenti pada siklus ini.

Kriteria keberhasilan penelitian ini dapat dilihat dari dua sisi, yaitu dari sisi proses dan dari sisi hasil. Dari sisi proses, keberhasilan penelitian ini dengan penerapan model pembelajaran yang dipilih sebagai alternatif pemecahan masalah.Sedangkan keberhasilan dari sisi hasil dapat dilihat dari meningkatnya prestasi hasil belajar siswa dan ketuntasan belajar siswa secara signifikan sesuai dengan acuan yang telah ditentukan dalam penelitian ini. Prinsip penilaian yang diterapkan di sini dapat mungkin mengacu pada Penilaian Berbasis Kelas atau Berbasis Peserta Didik, artinya penilaian dilakukan sepenuhnya oleh guru terhadap seluruh aspek dan proses kegiatan belajar siswa dengan isntrumen penilaian yang bervariasi dengan tetap memperhatikan perbedaan kemampuan individual siswa. Oleh karena itu Pedoman acuan penilaian yang ditentukan dalam penelitian ini untuk mengukur kemampuan penalaran induktif dan ketuntasan belajar siswa.Peningkatan kemampuanpenalaran induktif siswa melalui penerapan model Pembelajaran Contextual Teaching and Learning dikatakan meningkat secara signifikan manakala dari hasil evaluasi di akhir tindakan penelitian (siklus), seluruh siswa telah berhasil mencapai batas Kriteria Ketuntasan Minimal (KKM), kemampuan penalaran induktif siswa di sini dikatakan meningkat secara signifikan manakala nilai rata-rata hasil belajar siswa di akhir tindakan menunjukkan peningkatan sebesar $10 \%$ dari hasil belajar sebelumnya.Dengan begitu berarti menandai berakhirnya siklus pelaksanaan program tindakan.

\section{Hasil Penelitian dan Pembahasan Hasil Penelitian}

Setelah materi logika matematika diajarkan dengan menggunakan model pembelajaran CTL (Contextual Teaching and Learning) seperti yang tergambar pada rencana pembelajaran. Selanjutnya dilakukan tes akhir yang berjumlah 20 soal pilihan ganda berbentuk post tes dan 5 soal esai untuk pre tes yang bertujuan untuk mengukur sejauh mana tingkat kemampuan penalaran induktif siswa pada materi logika matematika yang telah disampaikan oleh peneliti dengan menggunakan model pembelajaran CTL (Contextual Teaching and Learning).

Berdasarkan tingkat kemampuan penalaran induktif siswa dapat dilihat bahwa terdapat 2siswa atau $10 \%$ dari 40 siswa yang tingkat kemampuan penalaran induktifnya tinggi, terdapat 5 siswa atau $20 \%$ tingkat kemampuan penalaran induktif sedang, terdapat 8 siswa atau $25 \%$ tngkat kemampuan penalaran induktifnya rendah,terdapat 25 siswa atau $45 \%$ tingkat kemampuan penalaran induktif siswa sangat rendah pada siklus I, sedangkan pada siklus II terdapat peningkatan penalaran induktif yaitu 26 siswa atau $70 \%$ dari 40 siswa tingkat kemampuan penalaran induktif siswa tinggi dan 12 siswa atau 25\% dari 40 siswa tingkat kemampuan penalaran siswa sedang,terdapat 2 siswa atau $10 \%$ dari 40 siswa tingkat kemampuan penalaran induktif siswa rendah. Dengan demikian pembelajaran materi logika matematika dengan menggunakan model pembelajaran CTL(Contextual Teaching and Learning) telah mencapai KKM. 
Tabel 4.1 Deskripsi Tingkat Kemampuan Penalaran Induktif Siswa

\begin{tabular}{cccc}
\hline $\begin{array}{c}\text { Presentase } \\
\text { Penalaran }\end{array}$ & $\begin{array}{c}\text { Tingkat } \\
\text { Penalaran }\end{array}$ & $\begin{array}{c}\text { Banyak } \\
\text { Siswa }\end{array}$ & \% Jumlah siswa \\
$90-100$ & Sangat Tinggi & 38 siklus II & $90 \%$ \\
$80-70$ & Tinggi & - & - \\
$69-60$ & Sedang & 22 siklus I & $55 \%$ \\
$59-50$ & Rendah & 28 siklus I & $45 \%$ \\
$49-0$ & Sangat Rendah & 2 siklus II & $10 \%$ \\
\hline
\end{tabular}

\section{Ketuntasan Belajar Siswa Secara Perseorangan dan Klasikal}

Berdasarkan tingkat kemampuan penalaran induktif siswa dapat dilihat bahwa terdapat 2 siswa atau $10 \%$ dari 40 siswa yang tingkat kemampuan penalaran induktifnya tinggi, terdapat 5 siswa atau $20 \%$ tingkat kemampuan penalaran induktif sedang, terdapat 8 siswa atau $25 \%$ tngkat kemampuan penalaran induktifnya rendah,terdapat 25 siswa atau $45 \%$ tingkat kemampuan penalaran induktif siswa sangat rendah pada siklus I, sedangkan pada siklus II terdapat peningkatan penalaran induktif yaitu 26 siswa atau $70 \%$ dari 40 siswa tingkat kemampuan penalaran induktif siswa tinggi dan 12 siswa atau 25\% dari 40 siswa tingkat kemampuan penalaran siswa sedang,terdapat 2 siswa atau $10 \%$ dari 40 siswa tingkat kemampuan penalaran induktif siswa rendah, belajar materi logika matematika dengan menggunakan CTL (Contextual Teaching and Learning).

Berdasarkan kriteria ketuntasan perseorangan dan klasikal, disimpulkan bahwa pembelajaran materi logika matematika dengan menggunakan model pembelajaran CTL (Contextual Teaching and Learning) telah memenuhi kriteria ketuntasan belajar siswa secara klasikal maupun individu.

\section{Pengujian Hipotesis}

Untuk pengujian hipotesis digunakan uji satu pihak dengan $\mathrm{dk}=(\mathrm{N}-1)$ dan peluang $(1-\alpha)$ dengan pengujian :

Tabel 1. Uji Hipotesis Peningkatan kemampuan Penalaran Induktif Matematik Siswa pada tabel free tes

$\begin{array}{cccccccc}\mathrm{N} & \bar{x}_{1} & \bar{x}_{2} & \bar{D} & \sum D^{2} & \left(\sum D\right)^{2} & t_{\text {hitung }} & t_{\text {tabel }} \\ 40 & 4,1 & 6,77 & 2,67 & 383 & 11881 & 11,41 & 1,68\end{array}$

Dari tabel dapat dilihat bahwa $t_{\text {hitung }}>t_{\text {tabel }}(11,41>1,68)$ yang berarti dalam pengujian $H_{o}$ ditolak dan $H_{a}$ diterima sehingga dapat disimpulkan bahwa metode Contextual Teaching and Learning dapat meningkatkan kemampuan penalaran induktif matematik siswa

Tabel 2. Uji Hipotesis Peningkatan Kemampuan Penalaran Induktif Matematik Siswa pada tabel post tes

$\begin{array}{cccccccc}\mathrm{N} & \bar{x}_{1} & \bar{x}_{2} & \bar{D} & \sum D^{2} & \left(\sum D\right)^{2} & t_{\text {hitung }} & t_{\text {tabel }} \\ 40 & 50,62 & 68,62 & 18 & 118 & 4356 & 89,10 & 1,68\end{array}$

Dari tabel dapat dilihat bahwa $t_{\text {hitung }}>t_{\text {tabel }}(89,10>1,68)$ yang berarti dalam pengujian $H_{o}$ ditolak dan $H_{a}$ diterima sehingga dapat disimpulkan bahwa metode Contextual Teaching and Learning dapat meningkatkan kemampuan penalaran induktif matematik siswa.

Tabel 3. Tabulasi Data pada post Tes Penalaran Induktif I dan Tes Penalaran II

\begin{tabular}{lllllll}
\hline \multicolumn{1}{c}{ Kategori } & TPKPI I & TPKPI II & Selisih & $t_{\text {hitung }}$ & $t_{\text {tabel }}$ & Kriteria \\
PKPIM $\geq$ & $\bar{x}_{1}=50,62$ & $\bar{x}_{2}=68,62$ & 18 & 89,10 & 1,68 & $\begin{array}{l}\text { Signitif } \\
(5 \%)\end{array}$ \\
$60 \%$ & $\bar{x}_{1}=4,1$ & $\bar{x}_{2}=6,77$ & 2,67 & 11,41 & 1,68 & \\
PKPIM $<$ & $\mathrm{N}=20$ & $\mathrm{~N}=38$ & $\mathrm{~N}=18$ & & & \\
& $(60 \%)$ & $(90 \%)$ & & & & \\
\hline
\end{tabular}


Berdasarkan tabel diatas dapat dijelaskan bahwa rata-rata skor yang diperoleh siswa pada tes penalaran I $\bar{x}=50,62$ juga terlihat bahwa siswa yang mencapai PKPIM $>60 \%$ sebanyak 22 siswa dan belum mencapai PKPIM $\geq 60 \%$ ada sebanyak 28 siswa. Setelah dilakukan perbaikan pada siklus II diperoleh rata-rata skor yang diperoleh siswa $\bar{x}_{2}=68,62$ masuk dalam kategaori baik. Pada siklus II terdapat 38 siswa (90\%) dan mencapai PKPIM $>60 \%$ dan 2 siswa $(10 \%)$ yang belum mencapai PKPIM. Selisih ratarata skor yang diperoleh siswa yang dihasilkan antar tes penalaran I dan tes penalaran II pada pengajaran mengunakan model pembelajaran Contextual Teaching and Learning adalah sebesar 18 dan berdasarkan persentase kemampuan penalaran induktif matematik siswa secara klasikal terjadi peningkatan kemampuan penalaran induktif matematik siswa yaitu sebesar $30 \%$ terlihat dari 22 siswa yang mencapai PKPIM $\geq 60 \%$ secara individual pada tes penalaran I menjadi 38 siswa yang mencapaiPKPIM $\geq 60 \%$ secara individual ( $90 \%$ secara klasikal). Dan melalui uji t hasil tes penalaran I dan tes penalaran II diperoleh diperoleh $t_{\text {hitung }}(89,10)>t_{\text {tabel }}(1,68)$ yang berarti bahwa pengajaran dengan model pembelajaran Contextual teaching and Learning dapat meningkatkan kemampuan penalaran induktif matematik siswa.

\section{Pembahasan Penelitian}

Dari penelitian pada kelas $X$ yang terdiri dari 40 siswa yang mengikuti pembelajaran Logika Matematika dengan menggunakan model pembelajaran CTL (Contextual Teaching and Learning) dapat meningkatkan kemampuan penalaran induktif matemati siswa pada materi logika matematika. Hal ini dapat dilihat dari peningkatan kemampuan penalaran induktif matematik siswa dalam menyelesaikan soal-soal matematika. Berdasarkan tingkat kemampuan penalaran induktif siswa dapat dilihat bahwa terdapat 2 siswa atau $10 \%$ dari 40 siswa yang tingkat kemampuan penalaran induktifnya tinggi, terdapat 5 siswa atau $20 \%$ tingkat kemampuan penalaran induktif sedang, terdapat 8 siswa atau $25 \%$ tngkat kemampuan penalaran induktifnya rendah,terdapat 25 siswa atau 45\% tingkat kemampuan penalaran induktif siswa sangat rendah pada siklus I, sedangkan pada siklus II terdapat peningkatan penalaran induktif yaitu 26 siswa atau $70 \%$ dari 40 siswa tingkat kemampuan penalaran induktif siswa tinggi dan 12 siswa atau $25 \%$ dari 40 siswa tingkat kemampuan penalaran siswa sedang,terdapat 2 siswa atau 10\% dari 40 siswa tingkat kemampuan penalaran induktif siswa rendah.

Dalam proses belajar mengajar dengan menerapkan model Contextual Teaching and Learning dalam menyelesaikan soal-soal logika matematika dapat membantu siswa untuk semakin menggunakan daya nalar dalam menyelesaikan soal, karena adanya keterlibatan siswa berfikir,sehingga pada saat siswa melakukan aktivitas pada setiap tahap model Contextual Teaching and Learning ini siswa akan menggunakan daya nalarnya. Pada CTL siswa dituntut untuk berfikir memecahan persoalan atau menentukan ide/konsep dalam pembelajaran. Melalui model CTL siswa dapat mengembangkan sifat ingin taunya dengan bertanya, pada model CTL juga siswa dapat melakukan refleksi pembelajaran tersebut.

Dengan demikian melalui pembelajaran dengan menggunakan model Contextual Teaching and Learning dapat meningkatkan penalaran induktif matematik siswa.pernyataan tersebut sejalan dengan pendapat Ruseni Wiasmari (2007) bahwa model pembelajaran Contextual Teaching and Learning adalah pembelajaran yang melibatkan siswa secara aktif dalam proses belajar. Temuan hasil penelitian lain juga didukung pernyataan diatas oleh peneliti yang dilakukan Febrianti Wulandari (2007) yang menyimpulkan bahwa model Contextual Teaching and Learningdapat meningkatkan kemampuan penalaran induktif matematik siswa.

\section{Kesimpulan} berikut :

Berdasarkan hasil analisis data yang diperoleh dapat ditarik kesimpulan dari hasil penelitian ini sebagai

1. Terdapat peningkatan yang signifikan tentang materi Logika Matematika semester II pada kelas $X$ SMA N 1 Torgamba.

2. Tingkat pencapaian hasil belajar siswa pada pembelajaran materi logika matematika dengan menggunakan model pembelajaran CTL (Contextual Teaching and Learning) adalah sedang

3. Secara klasikal atau perorangan ketuntasan belajar siswa telah mencapai KKM yaitu skor $80 \%$ atau 65 sudah mencapai ketuntasan KKM.

4. Pembelajaran pemecahan masalah pada topik menggunakan prinsip logika matematika dikelas $X$ semester 2 SMA N 1 Torgamba Tahun Ajaran 2013/2014 telah memenuhi kriteria efektivitas siswa. 
Jurnal Pembelajaran dan Matematika SIGMA (JPMS)

Vol .5 (No.1) Mei 2019

\section{Daftar Pustaka}

[1] Shadiq, Fadjar. 2004. Pemecahan masalah penalaran dan komunikasih.Yogyakarta: PPPG Matematika.

[2] Supinah. 2008. Pembelajaran Matematika SD dengan Pendekatan Kontekstual dalam melaksanakan KTSP. PPPPTKM

[3] Agus Suprijono. 2011. Model-Model Pembelajaran. Jakarta: Gramedia Pustaka Jaya.

[4] Arikunto, Suharsimi. 2006. Prosedur Penelitian Suatu Pendekatan Praktik. Jakarta: Rineka Cipta.

Pengaruh Peningkatan Kemampuan Penalaran Induktif Matematik Siswa pada Materi Logika Matematika dengan Menerapkan Model Pembelajaran Contextual Teaching and Learning kelas X-2 SMA Negeri 1 Torgamba 